AGRICA: Journal of Sustainable Dryland Agriculture, 14 (2): 102-112 (2021)

ISSN-Online: 2715-4955; ISSN-Cetak: 2715-6613

DOI: 1037478/agr.v14i2.963

\title{
DAMPAK CORONA VIRUS DISSEASE (COVID-19) TERHADAP PENJUALAN ANGGREK BULAN (Phalaenopsis amabilis) PADA PEDAGANG BUNGA TRADISIONAL DI DENPASAR
}

\author{
I Made Ananda Wiguna \\ Lulusan Magister Manajemen Agribisnis, Universitas Udayana, Denpasar, Indonesia. \\ E-mail :anandawigunaim@gmail.com
}

\begin{abstract}
The Impact Of Corona Virus Dissease (Covid-19) On The Sales Of Monthly Orchid (Phalaenopsis Amabilis) In Traditional Flower Traders In Denpasar. In the midst of the Covid-19 pandemic outbreak that is happening in Indonesia, many impacts are happening to the economy of the Indonesian people, one of which is the orchid plant trader in Denpasar City. This study aims to analyze the percentage of orchid sales in the month before the pandemic and during the Covid-19 pandemic and to find out the impact caused by the Covid-19 pandemic on the sales of moon orchids in Denpasar. The results showed that the total sales of orchids in the month before the pandemic were 3,800 trees, while the sales of orchids for the month of the pandemic in 2020 amounted to 925 so that there was a decrease of $75.65 \%$. There is a significant difference between the receipt of sales of orchids in the months before the Covid-19 pandemic and during the Covid-19 and the impact of the Covid19 pandemic on the sales of moon orchids, namely the decline in sales caused, among others, a decrease in tourists, the number of hotels closed, the elimination of major events so that causing a reduction in the circulation of money in the province of Bali, including in Denpasar.
\end{abstract}

Keywords: Covid-19 Pandemic, Phalaenopsis amabilis, Sales

\section{PENDAHULUAN}

Indonesia merupakan negara agraris yang terletak di daerahtropis dengan areal lahan pertanian yang luas, sebagian besar penduduk Indonesia hidup bergantung pada hasil pertanian salah satunya pada subsektor holtikultura. Hortikultura merupakan salah satu subsektor pertanian potensial dalam memberikan kontribusi terhadap pembangunan ekonomi dan memegang peranan penting dalam sumber pendapatan petani, perdagangan, maupun penyerapan tenaga kerja (Wahyudie, 2020). Komoditas tanaman hortikultura di Indonesia dapat dibagi menjadi empat kelompok besar, yaitu tanaman buahbuahan, sayuran, biofarmaka, dan tanaman hias. Salah satu subsektor hortikultura yang memberikan kontribusi pada Pendapatan Domestik Bruto yaitu tanaman hias. Perkembangan agribisnis tanaman hias yang begitu pesat timbul karena sektor ini 
Wiguna: Dampak corona virus dissease (Covid-19) terhadap penjualan anggrek bulan

sangat mudah digeluti dan mempunyai nilai ekonomi yang relatif tinggi (Utami, 2017).

Budidaya tanaman hias di Indonesia sangat cerah karena didukung oleh potensi pasar, baik dalam bentuk bunga hidup maupun bunga potong (Wadja et al., 2015).

Menurut Rohman (2019) baik tanaman hias daun maupun bunga dapat tumbuh dengan baik bila dibudidayakan di kondisi lingkungan yang tepat, seperti ketinggian tempat, kebutuhan air, dan cahaya. Tanaman anggrek adalah salah satu tanaman hias yang berkembang di Indonesia dan memiliki nilai ekonomi dan nilai estetika yang paling tinggi. (Yunita, 2018). Dalam literature (Cahyani, 2018) anggrek merupakan tanaman hias yang sangat populer dan disukai terutama di Indonesia salah satunya di Provinsi Bali. Provinsi Bali selain daerah pariwisata merupakan salah satu kawasan yang dimanfaatkan untuk berdagang tanaman hias khususnya anggrek bulan yang tersebar di beberapa daerah seperti kota Denpasar. Semakin banyaknya flowershop di Kota Denpasar persaingan semakin luas dan perusahaan harus mampu memiliki kelebihan untuk dapat menarik konsumen (Yanti et al., 2018).

Dewasa ini, dunia sedang mendapatkan pandemi hebat bernama Covid-19 (Corona Virus Disease). Virus tersebut dapat menyerang hewan dan manusia dengan gejala berupa infeksi yang serupa dengan penyakit SARS dan MERS, hanya saja Covid-19 bersifat lebih masif perkembangannya (Wahidah et al., 2020). Akibat dari pandemi covid-19 ini akan berdampak pada perekonomian global serta melemahkan peluang masyarakat dalam menghasilkan pendapatan sehari-harinya, terjadinya PHK besar-besaran pada pekerja yang mencapai 1.943 .916 orang yang terdiri dari 114.340 perusahaan (Mas'udi \& S. Winanti, 2020). Hal tersebut dibuktikan oleh catatan bahwa sejauh ini masih banyak orang yang terinfeksi Covid-19 dengan jumlah yang terus meningkat dikarenakan infeksi dan penyebaran virus Covid-19 ini sangat cepat (Hastuti et al., 2020).

Perkembangan wabah Covid-19 berdampak bagi perekonomian masyarakat Indonesia, termasuk pedagang tanaman anggrek bulan di Kota Denpasar. Semakin gencarnya promosi pariwisata mengakibatkan pertumbuhan perhotelan, restoran atau usaha-usaha pelayanan publik lainnya. Kesemua usaha itu pasti membutuhkan bunga hias untuk menambah nilai estetika, sehingga lebih menarik perhatian para pengunjung/ konsumen/ turis (Supiani \& Sinaini, 2020). Dampak covid19 sangat berpengaruh besar dalam berbagai sektor, khususnya bagi pelaku dan usaha pariwisata, apalagi Bali sangat mengandalkan sektor pariwisata (Purwahita et al., 2021). Semenjak pemberlakukan 
pembatasan pergerakan orang karantina parsial, serta ditutupnya akses pariwisata ke Bali sehingga banyak pedagang anggrek yang merugi karena pembeli sangat jarang bahkan tidak ada. Berdasarkan kondisi tersebut, maka penelitian ini dilakukan untuk mengetahui apakah terdapat perbedaan penjualan tanaman anggrek bulan sebelum dan setelah wabah Covid-19 serta langkah-langkah yang dilakukan pedagang dalam menghadapi pandemi tersebut. Adapun rumusan masalah dalam penelitian ini adalah bagaimana penjualan anggrek bulan selama pandemi Covid-19 dan bagaimana perbedaan penjualan anggrek pada tahun 2020 dibandingkan dengan 2019 serta apa saja dampak pandemic Covid-19 terhadap penjualan anggrek bulan di Denpasar.

Adapun tujuan yang ingin dicapai dari penelitian ini antara lain: (1) menganalisis persentase penjualan anggrek bulan selama masa pandemic, (2) bagaimana perbandingan penjualan anggrek bulan sebelum pandemic Covid-19 dan selama pandemic Covid-19 dan (3) mengetahuiapa saja dampak pandemic Covid-19 terhadap penjualan anggrek bulan di Denpasar.

\section{Bahan dan Metode}

\section{Waktu dan Lokasi Penelitian.}

Penelitian ini akan dilaksanakan terhadap pedagang anggrek tradisional yang berada di Seputaran Renon Denpasar selama tiga bulan yaitu bulan Januari sampai Maret 2021. Pemilihan lokasi ini dilakukan secara sengaja (Purposive) dengan pertimbangan bahwa Daerah Renon merupakan salah satu Kawasan penjual anggrek bulan tradisional di Daerah Denpasar.

\section{Metode Penentuan Sampel.}

Jumlah responden yang menjual anggrek bulan di Daerah Renon, Denpasar berjumlah tujuh (7) orang. Penarikan sampel menggunakan metode sampling jenuh dimana teknik penentuan sampel bila semua anggota populasi digunakan sebagai sampel. Populasi adalah wilayah generalisasi objek yang mempunyai kualitas dan karakteristik tertentu yang ditetapkan oleh peneliti untuk dipelajari dan kemudian ditarik kesimpulannya (Suharsaputra, 2012). Pengambilan sampel dilakukan atas dasar pendekatan langsung ke responden dengan panduan dari peneliti. Dalam hal ini, penulis akan mewawancarai responden sehingga dapat diperoleh informasi lebih dalam.

\section{Metode Pengumpulan Data}

Data yang digunakan dalam penelitian ini adalah data yang diperoleh melalui wawancara dengan responden, dengan bantuan kuisioner. Data ini merujuk pada hasil dari wawancara yang didapatkan dari para pedagang anggrek di Denpasar. Jumlah pedagang anggrek di kawasan 
Wiguna: Dampak corona virus dissease (Covid-19) terhadap penjualan anggrek bulan

Renon berjulmah 6 pedagang traditional yang cukup besar. Wawancara yang dilakukan adalah dengan melihat hasil penjualan sebelum pandemi Covid-19 dan setelah Covid-19. Kemudian, data diolah untuk mengetahui perbedaan yang terjadi, sebelum dan sesudah Pandemi Covid-19.

\section{Penerimaan (total revenue)}

Penerimaan dalam penelitian ini yaitu penerimaan dari penjualan usaha anggrek bulan sebelum pandemic Covid-19 dan selama pandemic Covid 19. Sebelum pandemic Covid-19 yaitu penerimaan pada tahun 2019 sedangkan data penerimaan selama pandemic Covid-19 yaitu tahun 2020. Penerimaan dari suatu proses produksi dapat dihitung dengan mengalikan jumlah produksi yang dihasilkan dengan harga jual produksi tersebut (Dewi et al., 2015). Pendapatan kotor (penerimaan) dapat dihitung dengan menggunakan rumus sebagai berikut (Simanjutak, 2021):

$$
\mathbf{T R}=\mathbf{Q} \cdot \mathbf{R}
$$

Keterangan :

$$
\begin{array}{ll}
\mathrm{TR} & =\text { Penerimaan Total (Rupiah) } \\
\mathrm{P} & =\text { Harga per satuan (Rupiah/Pohon) } \\
\mathrm{Q} & =\text { Jumlah Produksi (Pohon) }
\end{array}
$$

\section{Metode Perbandingan}

Dalam penelitian ini penulis menggunakan aplikasi microsoft excel 2010 digunakan untuk mengimput data dan pembuatan tabel serta SPSS 20 yang digunakan untuk mengelola data berupa uji normalitas dan uji beda dengan data statistik yang telah didapatkan oleh peneliti dengan mengumpulkan data responden yang berupa data primer. Data yang dimaksud dalam penelitian ini yaitu data penerimaan anggrek bulan pada tahun 2019 dan penerimaan anggrek bulan pada tahun 2020.

\section{HASIL DAN PEMBAHASAN}

\section{Persentase Penjualan Anggrek Bulan}

(Phalaenopsis amabilis) Tahun 2020

Penjualan anggrek bulan pedagang tradisional dihitung berdasarkan jumlah bunga yang dibeli dari distributor besar. Pedagang anggrek membeli dua jenis bunga anggrek bulan, jenis yang pertama adalah anggrek bulan standar yakni warna putih dan ungu. Jenis yang kedua adalah anggrek Bulan Novelty, anggrek bulan novelty adalah anggrek bulan dengan varian warna yang banyak dan lebih menarik. Anggrek bulan ini juga kerap disebut anggrek bulan koleksi. Anggrek bulan standar memiliki market yakni, Hotel, restaurant, perkantoran maupun florist untuk event-event tertentu. Sedangkan anggrek bulan novelty biasa dibeli oleh penghobby anggrek. Anggrek bulan ini dibeli dalam 1 box yang berisi 50 pohon. Tabel 1. Menunjukkan penjualan anggrek bulan selama masa pandemi Covid-19 pada usaha anggrek bulan di daerah seputaran Renon Denpasar. 
Tabel 1. Penjualan Anggrek Bulan pada Tahun 2020 dapat dilihat pada tabel berikut :

\begin{tabular}{|c|c|c|c|c|c|}
\hline \multirow{2}{*}{ No } & \multirow{2}{*}{ Bulan } & \multicolumn{2}{|c|}{ Anggrek Bulan } & \multirow{2}{*}{ Total } & \multirow{2}{*}{$\begin{array}{c}\text { Presentase } \\
\text { penjualan }\end{array}$} \\
\hline & & Standar & Novelty & & \\
\hline 1 & Januari & 1.800 & 1.200 & 3.000 & \\
\hline 2 & Februari & 1.680 & 1.120 & 2.800 & (-) $6,67 \%$ \\
\hline 3 & Maret & 600 & 400 & 1.000 & (-) $64,3 \%$ \\
\hline 4 & April & 150 & 350 & 500 & (-) $50 \%$ \\
\hline 5 & Mei & 150 & 350 & 500 & 0 \\
\hline 6 & Juni & 150 & 350 & 500 & 0 \\
\hline 7 & Juli & 150 & 250 & 400 & (-) $20 \%$ \\
\hline 8 & Agustus & 200 & 200 & 400 & 0 \\
\hline 9 & September & 150 & 350 & 500 & $(+) 20 \%$ \\
\hline 10 & Oktober & 150 & 250 & 400 & (-) $20 \%$ \\
\hline 11 & November & 150 & 250 & 400 & 0 \\
\hline 12 & Desember & 300 & 400 & 700 & $(+) 75 \%$ \\
\hline
\end{tabular}

Sumber: diolah dari data primer (2021)

Dari sini dapat dilihat jika penjualan bunga anggrek bulan pada januari 2020 masih cukup tinggi, yakni sebesar 3000 pohon dengan rincian penjualan anggrek bulan standar sebanyak 1.800 dan penjualan anggrek bulan novelty sebanyak 1.200. Banyaknya jumlah tersebut karena belum ditetapkannya situasi pandemi covid-19. Pada bulan Februari tahun 2020 sudah terjadi penurunan sebesar $6,67 \%$ dari tahun sebelumnya, yakni dengan total penjualan 2.800 pohon dengan rincian 1.680 anggrek bulan standar dan 1.120 anggrek bulan Novelty. Penurunan ini berakibat dari mulai berkurangnya wisatawan china, sehingga menurunkan pengeluaran yang dikeluarkan oleh hotel dengan market china. Penurunan terbesar terjadi pada Bulan Maret, yakni sebesar
64,3\%. Total penjualan pada bulan Maret adalah 1.000 pohon.

Pada bulan April 2021, penjualan anggrek bulan kembali mengalami penurunan yang cukup tinggi. Penurunan penjualan anggrek bulan turun sebesar $50 \%$ dengan penjualan total sebesar 500 pohon, dengan rincian penjualan anggrek bulan standar sebesar 150 pohon dan anggrek bulan novelty sebesar 350 pohon. Penjualan pada bulan Mei dan Juni tidak mengalami perubahan dan masih sama seperti bulan April dengan total penjualan 500 pohon. Dibulan Juli penjualan anggrek bulan Kembali mengalami penurunan sebesar 20\%. Total penjualan pada bulan Juli adalah sebesar 400 pohon, dengan rincian 150 pohon bunga anggrek bulan standar dan 250 pohon bunga anggrek bulan 
Wiguna: Dampak corona virus dissease (Covid-19) terhadap penjualan anggrek bulan

novelty. Penurunan ini disebabkan oleh kurangnya pasokan bunga pada bulan Juli.

Penjualan bunga pada bulan Agustus tidak mengalami perubahan, dan masih sama seperti bulan Juli. Komposisi penjualan anggrek bulan pada bulan agustus adalah 200 pohon untuk penjualan anggrek bulan standar dan 200 pohon untuk penjualan anggrek bulan novelty. Penjualan Kembali meningkat pada Bulan September. Peningkatan pada bulan September adalah sebesar 20\%. Total penjualan pada bulan September adalah 500 pohon, dengan rincian penjualan anggrek bulan standar yaitu 150 pohon dan anggrek bulan novelty 350 pohon. Pada bulan Oktober, penjualan anggrek bulan Kembali mengalami penurunan yakni dengan total penjualan 400 pohon, dengan rincian penjualan anggrek bulan standar 150 dan penjualan anggrek bulan novelty sebesar 250 pohon.

Pada bulan November, penjualan anggrek bulan sama seperti bulan Oktober.
Total penjualan anggrek bulan pada bulan November adalah sebesar 400 pohon. Peningkatan kembali terjadi pada penjualan bulan Desember. Penjualan bulan September meningkat menjadi 700 pohon dengan penjualan anggrek bulan standar 300 pohon dan anggrek bulan novelty 400 pohon. Peningkatan ini diakibatkan mulai dibukanya hotel menyambut tahun baru.

\section{Perbandingan Penjualan dan}

Penerimaan Anggrek Bulan Tahun 2020 dan 2019

Penerimaan Anggrek Bulan (Phalaenopsis amabilis) dihitung dengan mengkalikan volume penjualan dengan harga jual anggek bulan. Harga jual anggrek bulan standar adalah Rp100.000,00- dan Rp135.000,00 untuk penjualan anggrek bulan Novelty. Sehingga didapatlah hasil untuk perhitungannya seperti tabel berikut.Penjualan anggrek bulan pada tahun 2019 dapat dilihat pada Tabel 2. 
Tabel 2. Penjualan Anggrek Bulan (Phalaenopsis amabilis) Tahun 2019

\begin{tabular}{clrrrr}
\hline \multirow{2}{*}{ No } & \multirow{2}{*}{ Bulan } & \multicolumn{2}{c}{ Penjualan Tahun 2019} & & \multirow{2}{*}{ Penerimaan } \\
& Standar & Novelty & & \\
\hline 1 & Januari & 2280 & 1520 & $\mathrm{Rp}$ & $433,200,000.00$ \\
2 & Februari & 2280 & 1520 & $\mathrm{Rp}$ & $433,200,000.00$ \\
3 & Maret & 2100 & 1400 & $\mathrm{Rp}$ & $399,000,000.00$ \\
4 & April & 2100 & 1400 & $\mathrm{Rp}$ & $399,000,000.00$ \\
5 & Mei & 2220 & 1480 & $\mathrm{Rp}$ & $421,800,000.00$ \\
6 & Juni & 2460 & 1640 & $\mathrm{Rp}$ & $467,400,000.00$ \\
7 & Juli & 2280 & 1520 & $\mathrm{Rp}$ & $433,200,000.00$ \\
8 & Agustus & 2400 & 1600 & $\mathrm{Rp}$ & $456,000,000.00$ \\
9 & September & 2220 & 1480 & $\mathrm{Rp}$ & $421,800,000.00$ \\
10 & Oktober & 2280 & 1520 & $\mathrm{Rp}$ & $433,200,000.00$ \\
11 & November & 2340 & 1560 & $\mathrm{Rp}$ & $444,600,000.00$ \\
12 & Desember & 2400 & 1600 & $\mathrm{Rp}$ & $456,000,000.00$ \\
\hline & TOTAL & 27.360 & 18.240 & $\mathrm{Rp} 5.198 .400 .000 .00$ \\
\hline
\end{tabular}

Sumber: Diolah dari data primer (2021)

Berdasarkan Tabel 2 penerimaan dari penjualan anggrek bulan (Phalaenopsis amabilis) mengalami fluktuasi, dimana penerimaan terendah pada bulan maret dan bulan April. Hal tersebut dikarenakan kunjungan pariwisata ke Bali mengalami Tabel 3. Penjualan Anggrek Bulan(Phalaenopsis amabilis)Tahun 2020

\begin{tabular}{|c|c|c|c|c|c|}
\hline \multirow{2}{*}{ No } & \multirow{2}{*}{ Bulan } & \multicolumn{2}{|c|}{ Penjualan tahun 2020} & \multirow{2}{*}{\multicolumn{2}{|c|}{ Penerimaan }} \\
\hline & & Standar & Novelty & & \\
\hline 1 & Januari & 1800 & 1200 & $\mathrm{Rp}$ & $342,000,000.00$ \\
\hline 2 & Februari & 1680 & 1120 & $\mathrm{Rp}$ & $319,200,000.00$ \\
\hline 3 & Maret & 600 & 400 & $\mathrm{Rp}$ & $114,000,000.00$ \\
\hline 4 & April & 150 & 350 & $\mathrm{Rp}$ & $62,250,000.00$ \\
\hline 5 & Mei & 150 & 350 & $\mathrm{Rp}$ & $62,250,000.00$ \\
\hline 6 & Juni & 150 & 350 & $\mathrm{Rp}$ & $62,250,000.00$ \\
\hline 7 & Juli & 150 & 250 & $\mathrm{Rp}$ & $48,750,000.00$ \\
\hline 8 & Agustus & 200 & 200 & $\mathrm{Rp}$ & $47,000,000.00$ \\
\hline 9 & September & 150 & 350 & $\mathrm{Rp}$ & $62,250,000.00$ \\
\hline 10 & Oktober & 150 & 250 & $\mathrm{Rp}$ & $48,750,000.00$ \\
\hline 11 & November & 150 & 250 & $\mathrm{Rp}$ & $48,750,000.00$ \\
\hline 12 & Desember & 300 & 400 & $\mathrm{Rp}$ & $84,000,000.00$ \\
\hline \multicolumn{2}{|c|}{ TOTAL } & & 5470 & \multicolumn{2}{|c|}{$\operatorname{Rp} 1,301,450,000.00$} \\
\hline
\end{tabular}

Sumber: diolah dari data primer (2021)

Tabel 3 menunjukkan bahwa penerimaan dari penjualan anggrek bulan low season sehingga permintaan dari anggrek bulan menurun. Sedangkan untuk penjualan anggrek bulan (Phalaenopsis amabilis) pada tahun 2020 dapat dilihat pada Tabel 3. 
Wiguna: Dampak corona virus dissease (Covid-19) terhadap penjualan anggrek bulan

tersebut dikarenakan adanya pandemi Covid-19 yang menyebabkan perekonomian masyarakat maupun di bidang pariwisata menurun sehingga minat akan bunga anggrek bulan juga menurun.

Analisis Independent t-Test Penjualan Anggrek Bulan (Phalaenopsis amabilis) Sebelum Pandemic Covid-19 dan Selama Pandemic Covid-19.

Total rata-rata penjualan anggrek bulan pada tahun 2020 adalah 925 pohon, sedangkan pada tahun 2019, rata-rata penjualan anggrek bulan adalah sebesar 3.800 pohon. Perbedaan penjualan pada tahun 2020 dan 2019 adalah sebesar 2.875 atau yang berarti mengalami penurunan Tabel 4. Hasil Output Menggunakan SPSS 20

\begin{tabular}{llcccc}
\hline \multicolumn{5}{c}{ Group Statistics } \\
\hline Penjualan & Keadaan & N & Mean & Std. Deviation & Std. Error Mean \\
\hline & Pandemi & 12 & 3800.0000 & 185.86408 & 53.65434 \\
& 12 & 925.0000 & 939.17275 & 271.11582 \\
\hline
\end{tabular}

Sumber: Data diolah dari data primer (2021)

Berdasarkan Tabel diatas, diketahui jumlah data pada penelitian ini sebelum dan selama pandemic Covid-19 adalah 12. Nilai rata-rata penjualan anggrek bulan sebelum pandemi adalah 3800 pohon sementara rata-rata penjualan selama pandemic Covid-19 selama tahum 2020 adalah sebesar $75,65 \%$. Penurunan ini terjadi selain dikarenakan tutupnya hotel-hotel yang biasa menjadi market penyerap anggrek bulan terbesar di Bali, juga terjadi karena sempat ditutupnya penerbangan dan pembatasan penerbangan yang menjadikan cost transportasi/ ongkos kirim anggrek bulan menjadi lebih mahal.

Hasil analisis uji beda rata-rata diperoleh nilai signifikansi sebesar 0,008 $(<0,05)$ yang artinya terdapat perbedaan yang signifikan antara penjualan anggrek bulan (Phalaenopsis amabilis) sebelum pandemic Covid-19 dan selama pandemi Covid-19. 
AGRICA, VOL. 14, NO. 2 (2021)

Tabel 5. Hasil OutputIndependent Sample t-Test Pejualan Aggrek Bulan di Denpasar.

\section{Independent Samples Test}

Levene's Test for Equality of

Variances

t-test for Equality of Means

\begin{tabular}{|c|c|c|c|c|c|c|c|c|c|c|}
\hline & & \multirow[t]{2}{*}{$\mathrm{F}$} & \multirow[t]{2}{*}{ Sig. } & \multirow[t]{2}{*}{$\mathrm{t}$} & \multirow[t]{2}{*}{ Df } & \multirow[t]{2}{*}{$\begin{array}{l}\text { Sig. } \\
(2- \\
\text { tailed })\end{array}$} & \multirow[t]{2}{*}{$\begin{array}{c}\text { Mean } \\
\text { Difference }\end{array}$} & \multirow[t]{2}{*}{$\begin{array}{l}\text { Std. Error } \\
\text { Difference }\end{array}$} & \multicolumn{2}{|c|}{$\begin{array}{l}\text { 95\% Confidence } \\
\text { Interval of the } \\
\text { Difference }\end{array}$} \\
\hline & & & & & & & & & Lower & Upper \\
\hline \multirow[b]{2}{*}{$\begin{array}{l}\text { Penju } \\
\text { alan }\end{array}$} & $\begin{array}{l}\text { Equal } \\
\text { variances } \\
\text { assumed }\end{array}$ & 8.533 & 0.008 & 10.403 & 22 & 0 & 2875 & 276.373 & 2301.83 & 3448.16 \\
\hline & $\begin{array}{l}\text { Equal } \\
\text { variances } \\
\text { not } \\
\text { assumed }\end{array}$ & & & 10.403 & 11.86 & 0 & 2875 & 276.373 & 2272.04 & 3477.954 \\
\hline
\end{tabular}

Sumber: Data diolah dari data primer (2021)

Berdasarkan output diatas diketahui

Selanjutnya pada tabel mean nilai sig. Levene's Test for Equality of difference adalah sebesar 2875 pohon. Nilai Variancessebesar 0,008 $<0,05$ maka dapat ini menunjukkan selisih antara penjualan diartikan bahwa varians data antara anggrek bulan sebelum pandemic Covid-19 penjualan anggrek bulan sebelum pandemic Covid-19 dan selama pandemic Covid-19 adalah heterogen atau berbeda.

Berdasarkan tabel output pada bagian "Equal variances assumed" diketahui nilai Sig. (2-tailed) sebesar $0.000<0.05$ maka dapat disimpulkan bahwa H0 ditolak dan Ha diterima dengan hipotesis awal $\mathrm{HO}$ : Tidak ada perbedaan antara penjualan anggrek bulan sebelum dan selama pandemic Covid-19, sedangkan Ha: Terdapat perbedaan antara penjualan anggrek bulan sebelum dan selama pandemic Covid-19. Dengan demikian terdapat perbedaan yang signifikan antara penjualan anggrek bulan sebelum pandemic Covid-19 dan selama pandemic Covid-19. dan selama Covid-19 di Denpasar. Dan selisih perbedaan tersebut adalah 2301 sampai 3448 pohon.

\section{Dampak \\ Pandemi \\ Covid-19 \\ terhadapPenjualan Anggrek Bulan (Phalaenopsis amabilis)di Denpasar.}

Pandemic Covid-19 tidak hanya berimbas kepada bidang pariwisata namun pandemic Covid-19 juga menyebabkan terjadinya penurunan penjualan anggrek bulan (Phalaenopsis amabilis) yang signifikan khususnya di pedagang tradisional daerah Renon Denpasar. Adapun beberapa factor yang menyebabkan turunnya penjualan anggrek bulan pada pandemic Covid-19 diantaranya sebagai berikut:

a. Penurunan Wisatawan 
Wiguna: Dampak corona virus dissease (Covid-19) terhadap penjualan anggrek bulan

Berkurangnya wisatawan yang berkunjung ke Bali yang disebabkan oleh pandemi Covid-19, menyebabkan berkurangnya budget operational yang dikeluarkan oleh pihak Hotel. Sehingga banyak hotel yang memangkas budget yang biasanya digunakan untuk menghias hotel dengan anggrek bulan, namun budget tersebut digunakan untuk keperluan yang lebih mendesak.

b. Hotel Tutup

Banyaknya hotel-hotel yang tutup menyebabkan penurunan pembelian dari anggrek bulan. Hal ini disebabkan karena market utama dalam penjualan anggrek bulan di Bali adalah sektor pariwisata. Selain ditutupnya hotel, ditutupnya tempat publik juga mempengaruhi penurunan permintaan akan anggrek bulan.

c. Event-Event Besar Ditiadakan.

Pandemi Covid-19 tidak hanya berimbas kepada pelaku parawisata, namun juga berimbas kepada event atau acara besar yang menyebabkan kerumunan. Tidak adanya event-event besar juga menjadi penyebab turunnya permintaan anggrek bulan karena biasanya menjadi salah satu penyerap penjualan anggrek bulan.

\section{SIMPULAN}

Berdasarkan penelitian yang telah dilakukan, dapat diperoleh beberapa simpulan yaitu :

1. Total penjualan anggrek bulan sebelum pandemi adalah sebesar 3.800 pohon sedangkan penjualan anggrek bulan selama pandemi pada tahun 2020 adalah sebesar 925 atauterjadipenurunan sebesar $75,65 \%$.

2. Penerimaan penjualan anggrek bulan setelah pandemic Covid 19 mengalami penurunan akibat penurunan jumlah wisatawan, pengipan/hotel-hotel tutup, tidak terlaksananya event-event besar.

\section{UCAPAN TERIMAKASIH}

Penelitian ini dapat dilaksanakan dengan baik berkat bantuan dari berbagai pihak, untuk itu peneliti mengucapkan terimakasih kepada pihak yang telah membantu dalam penelitian ini khususnya Universitas Tabanan.

\section{DAFTAR PUSTAKA}

Cahyani, A. N. (2018). Pengaruh Pemberian Auksin Pada Media Agar Terhadap Pertumbuhan Tanaman Anggrek Bulan (Phalaenopsis sp) Secara In Vitro Sebagai Sumber Pembelajaran Biologi. Skripsi FKIP Universitas MUhammdiyah Malang.

Dewi, Ida Ayu Listia, I. K. S. K. W. C. (2015). Kinerja Usaha Tanaman Anggrek Bulan (Phalaenopsis Amabilis) pada PT Multi Agro Bali di Desa Sembung Kecamatan Mengwi Kabupaten Badung. Journal of Agribusiness and Agritourism, 
4(1), 37-46.

Hastuti, N., Djanah, S. N., Pascasarjana, M., \& Dahlan, U. A. (2020). Studi Tinjauan Pustaka: Penularan Dan Pencegahan Penyebaran Covid-19. An-Nadaa: Jurnal Kesehatan Masyarakat, 7(2), 70-76.

Mas'udi, W., \& S. Winanti, P. (2020). Tata Kelola Penanganan COVID-19 di Indonesia.

Purwahita, A. A. . R. M., Wardhana, P. B. W., Ardiasa, I. K., \& I Made Winia. (2021). Dampak Covid-19 terhadap Pariwisata Bali Ditinjau dari Sektor Sosial, Ekonomi, dan Lingkungan (Sebuah Tinjauan Pustaka). Jurnal Kajian Dan Terapan Pariwisata, 1(2), $\quad$ 68-80. https://doi.org/10.53356/diparojs.v1i2 .29

Rohman, M. (2019). Anggrek Bulan ( Phalaenopsis amabilis ) Di PT Budi Daya Anggrek Bulan ( Phalaenopsis amabilis ) Di PT Anugrah Anggrek Nusantara. 1-36.

Simanjutak, wahyunita. (2021). Analisis Kelayakan Usaha Dan Model Pemasaran Tanaman Anggrek Tiga Dolok ( Studi Kasus : Usaha Anggrek Nagori Tiga Dolok, Kec . Panribuan , Kab. Simalungun ) Business Feasibility Analysis and Marketing Model of Three Dolok Orchid Plant ( Case Study: Nag. XV(02), 110-115.

Suharsaputra, U. (2012). Metode Penelitian Kuantitatif, Kualitatif, dan Tindakan.

Supiani, S., \& Sinaini, L. (2020). Analisis Pendapatan Usaha Tanaman Hias (Studi Kasus UD. Rahma Nurseri di
Desa Bangunsari Kabupaten Muna). Paradigma Agribisnis, 3(1), 1. https://doi.org/10.33603/jpa.v3i1.363 4

Utami, I. W. (2017). Analisis Perilaku Konsumen terhadap Keputusan Pembelian (Issue June).

Wadja, S., Imran, S., \& Indriani, R. (2015). Pengaruh Tingkat Harga pada Volume Penjualan Tanaman Hias Anggrek di Kelurahan Tomulabutao Kecamatan Dungingi Kota Gorontalo. 1-40.

Wahidah, I., Athallah, R., Hartono, N. F. S., Rafqie, M. C. A., \& Septiadi, M. A. (2020). Pandemik COVID-19: Analisis Perencanaan Pemerintah dan Masyarakat dalam Berbagai Upaya Pencegahan. Jurnal Manajemen Dan Organisasi, 11(3), 179-188. https://doi.org/10.29244/jmo.v11i3.3 1695

Wahyudie, T. (2020). Pengelolaan Komoditas Hortikultura Unggulan Berbasis Lingkungan.

Yanti, L. P. N., Suamba, I. K., \& Dewi, I. A. L. (2018). Perkembangan Usaha Agribisnis Bunga Anggrek Vanda Potong pada Kembang Batur Anggrek Collection di Desa Sanur Kaja Denpasar. Jurnal Agribisnis Dan Agrowisata (Journal of Agribusiness and Agritourism), 101. https://doi.org/10.24843/jaa.2018.v07 .i01.p11

Yunita, R. (2018). Saluran pemasaran usaha tanaman anggrek bulan di kelurahan malino kecamatan tinggimoncong kabupaten gowa. 